BIG AND BRIGHT A History of the McDonald Observatory

History of Science Series, No. 4 


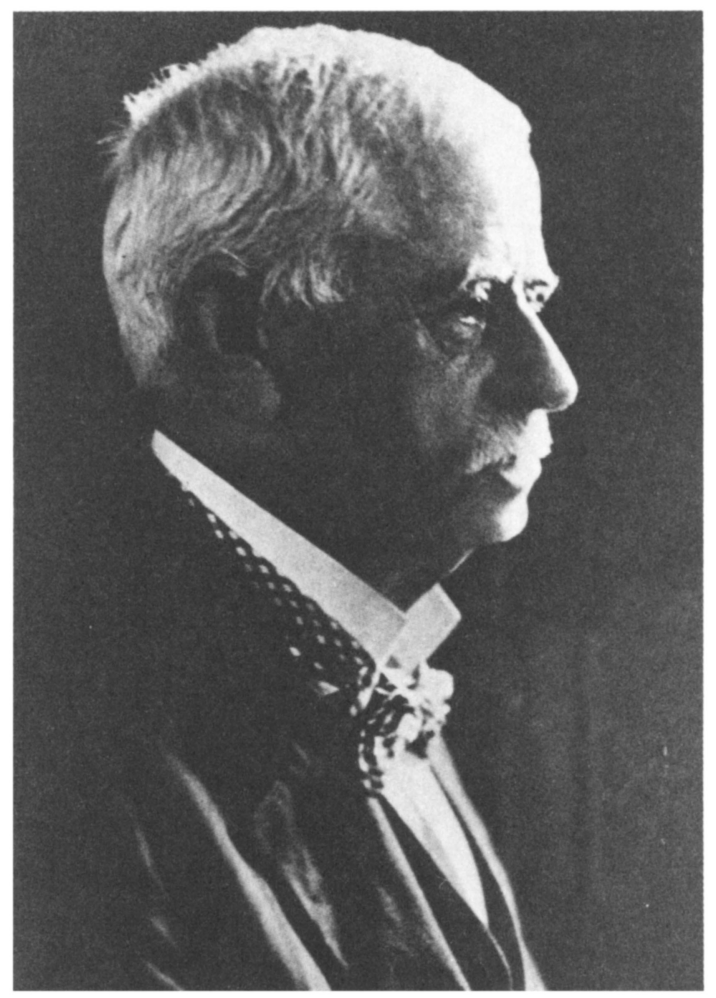

William Johnson McDonald (1844-1926) 


\section{BIG AND BRIGHT}

A History of the McDonald Observatory

by David S. Evans and J. Derral Mulholland

University of Texas Press, Austin

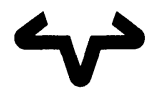


Copyright (C) 1986 by the University of Texas Press

All rights reserved

Printed in the United States of America

First edition, 1986

Requests for permission to reproduce material from this work should be sent to:

Permissions

University of Texas Press

Box 7819

Austin, Texas 78713-7819

\section{Library of Congress Cataloging-in-Publication Data}

Evans, David Stanley.

Big and bright.

(History of science series ; no. 4)

Includes index.

1. McDonald Observatory-History. 2. Astronomical observatories-Texas-Fort Davis-History. I. Mulholland, J. Derral (John Derral), 1934- II. Title.

III. Series.

QB82.U62F674 $1986 \quad 522^{\prime} .19764^{\prime} 934 \quad 86-7044$

ISBN 0-292-70759-2

Lyrics to Deep in the Heart of Texas on page xiv: words by June Hershey, music by Don Swander. Copyright 1941, Melody Lane Publications Inc. Copyright renewed by Melody Lane Publications Inc. International copyright secured. All rights reserved, including the right of public performance for profit. Controlled in Australia and New Zealand by Allan \& Co., Melbourne. Used by permission.

ISBN 978-0-292-75899-5 (library e-book)

ISBN 978-0-292-75900-8 (individual e-book) 
DEDICATED TO the achievements

of our predecessors and our colleagues, and especially to FRANK N. EDMONDS, JR., who led the way in Austin 
THIS PAGE INTENTIONALLY LEFT BLANK 